\title{
INMA

\section{Inklusi Keuangan Sektor UMKM melalui Pick Up Services yang Optimal}

\author{
Ade Maharini Adiandari ${ }^{1}$, Hendra Winata ${ }^{2}$
}

1. Universitas Ngurah Rai

2. Universitas Brawijaya

\begin{tabular}{|c|c|}
\hline INFO ARTIKEL & Abstract \\
\hline $\begin{array}{l}\text { Sejarah Artikel: } \\
\text { Diterima : } 2020 \\
\text { Diperbaiki : } 2020 \\
\text { Disetujui }: 2020\end{array}$ & \multirow[b]{2}{*}{$\begin{array}{l}\text { This study aims to see how the role of pick-up services in encouraging } \\
\text { MSME sector business owners to gain access to banking with the hope } \\
\text { that it will have an impact on the percentage increase in financial } \\
\text { inclusion in the MSME sector. Based on the data, the MSME sector } \\
\text { banking financial inclusion still needs to be improved. In this regard, } \\
\text { strategies and programs are needed to promote the affordability of } \\
\text { banking services to MSMEs in remote areas of Indonesia. } \\
\text { The study focuses on the Pick Up Services factor which is based on the } \\
\text { results of previous research as one of the influencing factors in helping } \\
\text { MSMEs ease into entering banking services. } \\
\text { The research method used is a qualitative case study method with } \\
\text { research subjects coming from two sides, both from the customer and } \\
\text { banking side. The use of qualitative methods is to find out more deeply } \\
\text { about the role of pick up services in encouraging the entry of MSMEs } \\
\text { into banking access. In addition, the study also investigates the form of } \\
\text { pick-up services that can provide optimal results for both MSME } \\
\text { customers and banks. The results of this study are the optimal pick-up } \\
\text { service calculation models and formulations for customers and banks } \\
\text { as a driving force for increased financial inclusion in the MSME sector } \\
\text { in Indonesia. }\end{array}$} \\
\hline $\begin{array}{l}\text { Keywords: } \\
\text { Financial Inclusion, Pick up } \\
\text { Services, SME Sector }\end{array}$ & \\
\hline & Abstraks \\
\hline $\begin{array}{l}\text { Kata Kunci: } \\
\text { Inklusi Keuangan, Pick up } \\
\text { Services, Sektor UMKM }\end{array}$ & \multirow[b]{2}{*}{$\begin{array}{l}\text { Studi ini memiliki tujuan untuk melihat bagaimana peran pick } \\
\text { up services dalam mendorong para pemilik usaha sektor } \\
\text { UMKM untuk memperoleh akses perbankan dengan harapan } \\
\text { dapat berdampak kepada persentase peningkatan inklusi } \\
\text { keuangan sektor UMKM. Berdasarkan data, inklusi keuangan } \\
\text { perbankan sektor UMKM masih perlu ditingkatkan. Terkait hal } \\
\text { ini, maka dibutuhkan strategi dan program untuk mendorong } \\
\text { keterjangkauan layanan perbankan sampai ke UMKM yang } \\
\text { berada di pelosok-pelosok Indonesia. } \\
\text { Studi menitikberatkan pada faktor Pick Up Services yang } \\
\text { berdasarkan hasil penelitian sebelumnya merupakan salah satu } \\
\text { faktor yang berpengaruh dalam membantu kemudahan UMKM } \\
\text { untuk masuk dalam layanan perbankan. } \\
\text { Metode penelitian yang digunakan adalah metode kualitatif } \\
\text { studi kasus dengan subjek penelitian berasal dari dua sisi, baik } \\
\text { dari sisi nasabah maupun perbankan. Penggunaan metode }\end{array}$} \\
\hline DOI: & \\
\hline
\end{tabular}




\begin{tabular}{|l|l|}
\hline & $\begin{array}{l}\text { kualitatif untuk mengetahui secara lebih mendalam bagaimana } \\
\text { peran pick up services dalam mendorong masuknya UMKM ke } \\
\text { dalam akses perbankan. Selain itu, studi juga menyelidiki } \\
\text { bentuk pick up services yang dapat memberikan hasil yang }\end{array}$ \\
& $\begin{array}{l}\text { optimal, baik bagi nasabah UMKM maupun pihak perbankan. } \\
\text { Hasil dari studi ini adalah model serta formulasi perhitungan } \\
\text { pick up services yang paling optimal bagi nasabah dan } \\
\text { perbankan sebagai pendorong terjadinya peningkatan inklusi }\end{array}$ \\
\hline $\begin{array}{l}\text { Korespondensi: } \\
\text { Nama: Ade Maharini Adiandari } \\
\text { Email: maharini.adiandari@unr.ac.id }\end{array}$ & ISSN: 2355-9643 (Print) \\
\hline
\end{tabular}

\section{PENDAHULUAN}

Inklusi keuangan merupakan poin penting dalam pembangunan ekonomi inklusif di Indonesia dimana seluruh masyarakat, khususnya masyarakat lapisan bawah seharusnya dapat berpartisipasi dan terakses pada layanan perbankan, terutama layanan simpanan dan pinjaman (Maharini \& Winata, 2017).

Inklusi keuangan pada level organisasi yang sangat penting dalam perspektif dunia adalah inklusi keuangan sektor UMKM mengingat peran UMKM yang sangat besar, diantaranya sebagai penyerap tenaga kerja serta penyedia utama kebutuhan pokok untuk golongan masyarakat berpenghasilan rendah. Semakin pesat pertumbuhan ekonomi suatu negara, maka semakin maju kondisi bisnis UMKM di negara tersebut. Data menunjukkan bahwa jumlah UMKM di Indonesia saat ini mencapai 56,4 juta di tahun 2014, namun di sisi lain, data juga menunjukkan bahwa tingkat inklusi keuangan perbankan sektor UMKM masih sangat rendah. Persoalan klasik seputar pembiayaan dan pengembangan usaha masih menajdi permasalahan yang melekat pada UMKM. Inklusi keuangan perbankan sektor UMKM di sisi pembiayaan hanya mencapai 30\% (LPPI, 2015). Dari persentase tersebut, sebanyak $76,1 \%$ mendapatkan kredit dari bank dan $23,9 \%$ dari non bank, seperti koperasi. Selebihnya, sebesar $60 \%-70 \%$ dari seluruh sektor UMKM belum memiliki akses pembiayaan melalui perbankan. Data ini menunjukkan bahwa sektor UMKM di Indonesia masih mengalami kesulitan dalam mengakses layanan perbankan.

Kesulitan UMKM dalam mengakses layanan perbankan juga disampaikan oleh
Schiffer dan Weder (2001) serta Beck et al. (2002) dalam hasil penelitiannya yang menyatakan bahwa perusahaan kecil menghadapi tantangan yang lebih besar dalam memperoleh akses keuangan dibandingkan dengan perusahaan besar. Data dari Global Financial Development Report (2014) juga memaparkan bahwa sebesar 76\% responden menyatakan bahwa masuk ke dalam akses keuangan merupakan penghalang signifikan bagi pertumbuhan usaha kecil di negaranya.

Selanjutnya terkait faktor-faktor yang dapat membantu kemudahan UMKM dalam mengakses layanan perbankan diantaranya disebutkan oleh beberapa peneliti adalah faktor lokasi perusahaan, ketersediaan laporan keuangan yang diaudit, persepsi pemilik tentang akses ke keuangan (Gamage, 2013), ukuran perusahaan, administrasi yang sederhana, prosedur pinjaman jangka panjang yang diberikan (Belanova, 2013), pemecahan hambatan atas eksklusivitas diri dan eksklusivitas pemasaran (Sun \& Siagian, 2015), proses sederhana, layanan penjemputan, preferensi (Maharini \& Winata, 2017), pengumpulan uang tunai (Ashraf et al, 2006), pengumpulan uang tunai secara langsung (De Mel et al, 2013).

Dari banyaknya faktor-faktor yang dapat mendorong masuknya UMKM ke dalam sektor perbankan, terdapat salah satu faktor yang dalam beberapa penelitian sebelumnya secara berulang disampaikan oleh pemilik UMKM sebagai faktor yang sangat dibutuhkan oleh UMKM, khususnya UMKM skala mikro dimana skala usaha masih sangat kecil dan lokasi usaha cukup jauh dari kantor cabang bank. Maharini dan Winata (2017) menyatakan bahwa program Pick up service merupakan layanan jemput bola yang 
dikehendaki oleh nasabah, baik dari sisi simpanan maupun pembiayaan agar tidak mengganggu jalannya usaha mengingat aktor utama UMKM adalah pemilik langsung.

Walaupun dalam penelitian sebelumnya, faktor layanan pick up services ini telah terbukti sebagai salah satu pendorong UMKM masuk dalam akses perbankan, namun dalam praktiknya, pelayanan pick up services tersebut tidaklah mudah dilaksanakan oleh perbankan. Hal ini mengingat adanya beberapa faktor yang harus dipertimbangkan oleh perbankan sebelum memutuskan memberikan layanan ini kepada nasabah, terlebih lagi apabila layanan ini tidak berbiaya atau gratis. Di Indonesia, secara umum, layanan ini telah diberikan oleh beberapa Bank Perkredian Rakyat (BPR) atau Bank Pembangunan Daerah (BPD) kepada nasabah-nasabahnya.

Dengan pertimbangan untuk menemukan solusi yang sama-sama menguntungkan bagi pihak nasabah maupun pihak bank, maka peneliti tertarik untuk menggali lebih dalam terkait bagaimana peran pick up services dalam mendorong sektor UMKM untuk masuk ke dalam akses perbankan serta bagaimana formulasi perhitungan dan model pick up services yang paling optimal bagi pihak UMKM maupun pihak perbankan.

\section{METODE PENELITIAN}

Penelitian ini menggunakan jenis penelitian kualitatif dengan pendekatan studi kasus. Creswell (2014) menyatakan bahwa studi kasus merupakan strategi penelitian dimana peneliti menyelidiki secara seksama suatu peristiwa, program, proses serta aktivitas dari suatu individu maupun kelompok. Subjek dalam penelitian ini berasal dari 2 pihak, yaitu pihak UMKM dan pihak bank. Dari pihak UMKM, subjek terdiri dari 10 pemilik UMKM dengan komposisi 7 subjek yang belum pernah menggunakan jasa pick up services dari bank serta 3 subjek lainnya yang pernah atau telah menggunakan jasa pickup services dari bank. Sedangkan dari pihak bank, terdapat 3 subjek yang terdiri dari 1 orang kayawan level pimpinan, 1 orang karyawan di bidang operasional dan 1 orang di bidang pemasaran yang terkait dengan keputusan untuk memberikan layanan pick up services kepada nasabahnasabah bank.

Teknik pengumpulan data yang digunakan dalam penelitian ini adalah observasi kualitatif dan wawancara mendalam.. Observasi kualitatif dilakukan peneliti dengan cara turun langsung ke lapangan untuk mengamati aktivitasaktivitas individu dilapangan. Sedangkan wawancara mendalam dilakukan secara tatap muka dengan menggunakan pertanyaan yang bersifat terbuka dan secara umum tidak terstruktur.

Dalam penelitian ini digunakan langkahlangkah analisis seperti yang disampaikan oleh Creswell (2014), meliputi 1) mengolah dan mempersiaplan data untuk dianalisis, 2) membaca keseluruhan data, 3) melakukan pengkodean data yang merupakan proses mengorganisasikan data dengan mengumpulkan potongan teks serta menuliskan kategori dalam batas-batas (Rossman \& Rallis, 2012), 4) mengidentifikasi tema, 5) membuat narasi atau laporan kualitatif, 6) membuat interpretasi penelitian

Selanjutnya proses pengkodean menggunakan 8 langkah pengkodean yang disampaikan oleh Tesch (1990), yang intinya meliputi 1) pemahaman hasil wawancara, 2) penemuan makna dasar, 3) penyusunan daftar topik dan penggabungan topik-topik yang sama, 4) Pemeringkasan topik ke dalam kode, 5) penetapan kalimat atau kata yang paling sesuai dalam menggambarkan topik ke dalam kategori-kategori, 6) Penyusunan materi data ke dalam setiap kategori, 7) Pengkodean data-data yang sudah ad ajika dibutuhkan. Sebagai informasi, kode-kode di susun berdasarkan informasi yang muncul dengan sendirinya dari para partisipan, yang biasa disebut dengan emerging code dan bukan dari kode-kode yang telah ditentukan sebelumnya atau yang disebut dengan predetermined code.

\section{Hasil penelitian dan Diskusi}

Dari pengamatan dan proses wawancara mendalam yang dilakukan terhadap 10 subyek penelitian, pemilik UMKM, 7 diantaranya belum pernah menggunakan sedangkan 3 subjek lainnya pernah atau telah menggunakan jasa pickup services dari bank. 
Hasil interview berupa daftar jawaban dari pertanyaan yang diajukan kemudian dilakukan analisis secara menyeluruh dengan membaca seluruh data. Selanjutnya dilakukan pengelompokan dan pengkodean serta melakukan penulisan atas data yang diperoleh. Dari pengamatan dan pengkodean tersebut kemudian diambil beberapa tema besar dan selanjutnya melakukan penulisan serta interpretasi data.

Berdasarkan analisis terhadap data yang diperoleh dari wawancara dengan 10 nasabah bank, terdapat beberapa poin penting yang disampaikan. Beberapa hal yang disampaikan tersebut kemudian dikelompokkan ke dalam 5 kategori tema besar. Hasil dari analisis atas data, khususnya untuk pick up services pada produk simpanan (cash pick up) yang telah diolah dapat dilihat sesuai dengan tabel 1 dan 2 berikut ini:

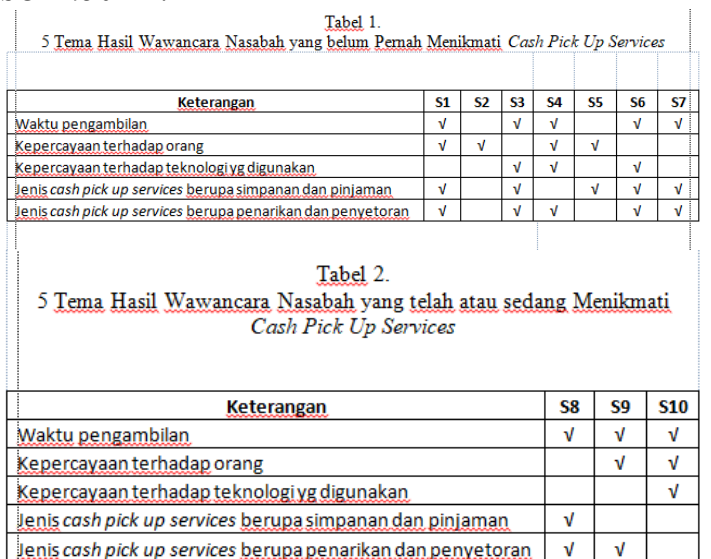

Dari tabel 1 dan 2 di atas, dapat diketahui bahwa tidak ada perbedaan yang mendasar antara nasabah yang saat ini telah menikmati fasilitas dan nasabah yang belum menikmati fasilitas cash pick up services. Apabila ditelaah lebih lanjut tampak bahwa waktu pengambilan menjadi suatu hal mendasar yang tampaknya menjadi sebuah keharusan dalam layanan pick up services bagi nasabah yang telah menikmati layanan cash pick up. Waktu pengambilan menjadi penting karena akan meningkatkan efisiensi dan pengambilan saat jumlah arus kas dari suatu usaha tersebut telah terkumpul seluruhnya untuk dapat disetorkan kepada bank.

Ada 2 hal menarik yang muncul juga dari penelitian ini, dimana baik nasabah yang telah menikmati layanan cash pick up maupun yang belum menikmati layanan tersebut menyatakan bahwa kepercayaan terhadap orang dan teknologi yang digunakan menjadi sesuatu yang juga penting. Kepercayaan terhadap orang dan teknologi yang digunakan ini adalah suatu hal yang wajar, mengingat kepercayaan adalah bisnis dasar dari sebuah bank. Kepercayaan terhadap orang tidak hanya dari pola penghitungan uang yang diharapkan oleh nasabah, namun juga dalam proses berinteraksi dengan petugas bank. Proses penghitungan uang dilakukan dengan 2 cara, yaitu dihitung satu persatu per coupers uang atau pilihan lainnya yakni dihitung secara gelondongan dalam 1 ikatan uang untuk kemudian dilakukan penghitungan satu persatu di bank dengan menggunakan mesin hitung uang. Dari pengamatan dan hasil diskusi dengan petugas bank diperoleh informasi bahwa untuk beberapa nasabah yang melakukan penyetoran uang secara kontinyu dan diambil setiap hari dengan jumlah yang besar, biasanya memilih untuk menggunakan pilihan dengan mengitung uang setiap 1 ikatan, dimana setiap ikatan terdiri dari 100 lembar uang kertas. Hal ini dipilih mengingat kecepatan proses pengambilan dan penghitungan uang secara lebih efisien. Demikian pula hal nya dengan tingkat kepercayaan yang sudah mulai tinggi di antara nasabah dengan petugas bank yang melakukan pengambilan uang tersebut.

Jenis layanan cash pick up yang dikehendaki nasabah tidak hanya proses penyetoran saja, namun juga proses pengambilan uang yang diantar langsung sesuai dengan keperluan nasabah. Hal ini tampaknya harus menjadi perhatian dari pihak bank untuk dapat melakukan layanan sesuai yang dikehendaki oleh nasabahnya.

Dari hasil wawancara mendalam terhadap 10 nasabah, terdapat 5 orang nasabah yang sekaligus menginginkan untuk layanan pick up services tidak sebatas di produk simpanan, namun juga pada produk pinjaman dalam bentuk pengambilan angsuran pinjaman. Hal ini harus menjadi perhatian pihak bank dimana penambahan pick up services pada produk pinjaman secara umum dapat menjadi nilai tambah bagi bank di dalam formulasi perhitungan pick up services yang optimal. Optimalisasi tersebut diperoleh dari efisiensi waktu dan biaya karena adanya penggabungan pick up services untuk produk simpanan dan 
pinjaman. Selanjutnya sebagai perhitungan dasar biaya pick up services yang optimal, maka dilakukan perhitungan biaya pick up services berdasarkan produk simpanan (cash pick up).

Selanjutnya temuan menarik yang disampaikan oleh 3 petugas bank dari jenjang yang berbeda, dapat dilihat pada tabel 3 berikut ini:

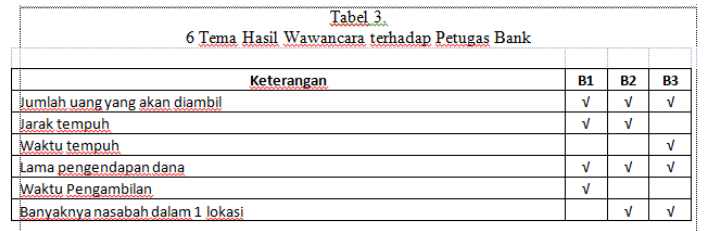

Dari tabel 3, dapat diketahui bahwa petugas bank ternyata lebih memiliki fokus pada jumlah uang yang akan diambil. Saat dikonfirmasi lebih dalam dari data yang disampaikan terungkap bahwa jumlah uang menjadi satu hal penting mengingat beberapa pertimbangan untuk persiapan proses prosedur pengambilan uang. Adapun beberapa prosedur pengambilan uang terkait dengan jumlah uang yang harus diperhatikan oleh petugas bank yaitu tentang jumlah petugas, asuransi cash in transit, petugas keamanan yang akan mengawal, alat transportasi yang akan digunakan serta proses untuk instalasi alat EDC (Electronic Data Capture) yang akan digunakan. Semakin banyak jumlah uang yang akan diambil dalam satu siklus pengambilan, maka semakin banyak jumlah petugas, jumlah tenaga keamanan dan jumlah asuransi yang akan digunakan. Demikian juga dengan alat transportasi dan proses instalasi EDC untuk memberikan kenyamanan dan meningkatkan kepercayaan kepada nasabah.

Jarak tempuh dan waktu tempuh serta banyaknya nasabah menjadi faktor yang juga harus diperhatikan menurut petugas bank. Hal ini diperlukan untuk mengatur jalur pengambilan, penentuan waktu pengambilan dan proses penyetoran atau penyerahan uang sebelum kembali bertugas. Artinya, petugas bank akan memperhatikan faktor efisiensi yang dihitung dari jarak tempuh, waktu tempuh dan waktu pengambilan uang untuk seluruh nasabah yang akan dilakukan cash pick up pada satu siklus pengambilan. Satu siklus pengambilan ini, yakni waktu yang dihitung sejak petugas bank keluar dari kantor bank, melakukan pengambilan uang untuk beberapa nasabah sesuai dengan jalur atau cluster yang ditentukan, sampai kembali menyetorkan uang yang telah diambil tersebut ke kantor bank. Sebagai tambahan informasi, petugas bank yang melakukan proses pengambilan ini bisa jadi juga melakukan proses tambahan atau setoran kas untuk beberapa unit kerja bank yang bersangkutan di lokasi yang berdekatan dengan nasabah.

Selanjutnya lama pengendapan dana menjadi faktor pertimbangan bagi petugas bank terkait dengan pengenaan biaya terhadap layanan cash pick up tersebut. Semakin lama dana mengendap di bank, maka keuntungan yang diperoleh bank atas pengendapan dana tersebut semakin besar, sebaliknya apabila dana yang diambil ternyata tidak mengendap di bank, maka keuntungan yang diperoleh oleh bank akan semakin rendah pula. Dengan demikian, untuk nasabah yang pengendapan dananya sesuai perhitungan pengendapan dana bank dapat dilakukan dengan gratis atau tanpa dikenakan biaya. Sedangkan untuk pengendapan dana yang sedikit di bank, maka bank akan mengenakan biaya tertentu untuk pengambilan tersebut.

Sesuai dengan hasil wawancara, dapat diperoleh informasi mengenai beberapa faktor-faktor biaya yang dipertimbangkan oleh bank dalam melakukan cash pick up services ini, diantaranya adalah jumlah petugas bank yang ditugaskan untuk melakukan pengambilan (biasanya 1 petugas bank, 1 tenaga sopir, 1 tenaga keamanan). Untuk jumlah tertentu sesuai dengan batas yang ditentukan oleh pihak asuransi, maka pihak bank harus menyertakan tenaga keamanan yang dipersenjatai dengan menggunakan senjata api. Selain itu terdapat faktor asuransi cash in transit yang harus dideklarasikan kepada pihak asuransi setiap melakukan proses perpindahan uang kas (dalam hal ini pengambilan uang kepada nasabah). Jumlahnya sesuai dengan persentase tertentu yang telah diseapakati antara pihak bank dan pihak asuransi kerugian. Faktor lainnya yang diperhatikan adalah tentang penggunaan kendaraan, yang dipertimbangkan adalah jarak tempuh dan waktu tempuhnya. Pihak bank mengembangkan sendiri formulasi untuk penghitungan benefit and cost ratio dari program cash pick up dengan formulasi sebagai berikut: 


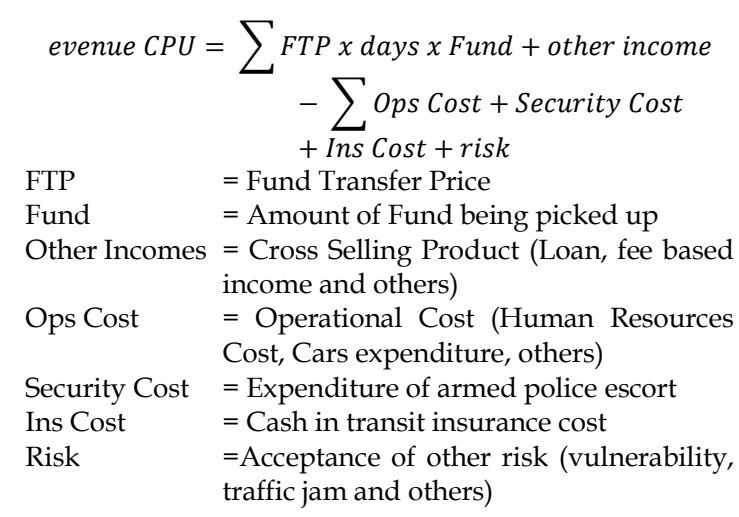

Formulasi tersebut di atas biasanya diterapkan untuk penerapan cash pick up dalam satu siklus. Artinya bahwa penghitungan dimulai sejak petugas dalam satu team pick up service berangkat dari kantor bank, kemudian melakukan beberapa cash pick up sampai kembali ke kantor dan menyerahkan uang. Komponen security cost dan insurance cost merupakan komponen yang berasal dari pihak ketiga di luar bank. Sedangkan untuk FTP biasanya telah ditetapkan oleh setiap bank masing-masing dengan perhitungan tertentu sesuai dengan biaya yang harus dikeluarkan untuk mendapatkan sejumlah dana tertentu. Penetapan FTP dilaksanakan oleh kantor pusat dalam hal ini biasanya dilaksanakan oleh Divisi Treasury.

\section{KESIMPULAN}

Dari hasil penelitian dapat disimpulkan bahwa terdapat lima tema utama yang merupakan hal penting harapan nasabah terkait pick up services, yaitu: 1) waktu pengambilan, 2), kepercayaan terhadap orang, 3) kepercayaan terhadap teknologi yang digunakan, 4) jenis cash pick up services berupa pendanaan dan pinjaman, 5) jenis cash pick up services berupa penarikan dan penyetoran. Berdasarkan temuan lebih lanjut dari pihak bank dapat diketahui bahwa terdapat 6 tema utama untuk menyediakan pick up services. Keenam tema utama tersebut adalah: 1) jumlah pengambilan uang, (2) jarak tempuh, (3) waktu tempuh, (4) lama pengendapan dana, (5) waktu pengambilan, (6) jumlah nasabah dalam 1 lokasi. Temuan penting lainnya adalah bahwa Bank harus memperhitungkan rasio manfaat dan biaya yang ditunjukkan dalam formulasi untuk melakukan analisis pick up services.
Selanjutnya penelitian di masa mendatang diperlukan penelitian terkait perkembangan teknologi digital untuk pick up services.

\section{DAFTAR PUSTAKA}

Ashraf, N., Dean, K., Yin, W. (2006). Deposit Collectors. B E Journal of Economic Analysis and Policy : Advances in Economic Analysis and Policy 6 (2).

Bank Indonesia and LPPI. Working paper 2015. Profil Bisnis Usaha Mikro, Kecil \& Menengah (MSMES).

Beck, T., Demirguc-Kunt, a., Maksimovic, V. (2002). Financing Pattern Around the World: The Role of Institutions, Policy Research Working Paper 2905. World Bank, Washington D.C.

Belanova, K. (2013). Access to Finance of Small and Medium Sized Enterprises in Slovakia. Economic Review.

Cresswell, John W. (2003). Research Design: Qualitative, Quantitative, and Mixed Methods Research (2nd ed) Thousand Oaks, CA:Sage.

De Mel, S., McIntosh, C., Woodruff, C. (2013). Deposit Collecting: Unbundling the Role of Frequency, Salience and Habit Formation in Generating Saving. American Economic Review: Papers \& Proceedings 103(3).

De Mel, S., et. al. (2013). Does Time and Distance Really Matter in Banking ? Evidence from Randomized Controlled Trial Introducing Mobile Phone Saving Deposits.

Gamage, P. (2013). Determinants of Access to Bank Finance for Small and Medium

Sizes Enterprises : The Case of Srilanka. Corporate Ownership \& Control Volume 10, issue 3.

Global Financial Development Report (2014).

Lincoln, Y.S. and Guba, E. (1985). Naturalistic Inquiry. Sage Publications Inc., Newbury Park, CA.

Maharini, A., Winata, H. (2018). Financial Inclusion in Indonesia: Application of MSME Accelerating Model to Access Bank Financing. Review of Integrative Business and Economics Research, Vol 7, Supplementary Issue 1 (forthcoming).

Otoritas Jasa Keuangan (2015). Buku Seputar Informasi Mengenai Layanan 
Keuangan Tanpa Kantor Dalam

Rangka Keuangan Inklusif.

Departemen Penelitian dan Pengaturan

Perbankan.

Schiffer, m., Weder, B. (2001). Firm Size and

The Business Environment: Worldwide

Survey Results. Discussion Paper 43,

International Finance Corporation,

Washington D.C.

Sun, Y., \& Siagian, P. (2015). Financial

Inclusion in Indonesia and Its

Challenges. Pertanika J. Soc. Sci. \&

Hum. 23 (S): 85 - 96 (2015). 